\title{
Rainfall interception and spatial variability of throughfall in spruce stand
}

\author{
Michal Dohnal $^{1 *}$, Tomáš Černý ${ }^{1}$, Jana Votrubová ${ }^{1}$, Miroslav Tesař ${ }^{2}$ \\ ${ }^{1}$ Czech Technical University in Prague, Faculty of Civil Engineering, Thákurova 7, 166 29, Prague, Czech Republic. \\ ${ }^{2}$ Institute of Hydrodynamics of the Academy of Sciences of the Czech Republic, Pod Patankou 5, Prague 6, Czech Republic. \\ ${ }^{*}$ Corresponding author. Tel.: +420 22435 5404. E-mail: dohnalm@mat.fsv.cvut.cz
}

\begin{abstract}
The interception was recognized as an important part of the catchment water balance in temperate climate. The mountainous forest ecosystem at experimental headwater catchment Liz has been subject of long-term monitoring. Unique dataset in terms of time resolution serves to determine canopy storage capacity and free throughfall. Spatial variability of throughfall was studied using one weighing and five tipping bucket rain gauges. The basic characteristics of forest affecting interception process were determined for the Norway spruce stand at the experimental area - the leaf area index was $5.66-6.00 \mathrm{~m} \mathrm{~m}^{2}$, the basal area was $55.7 \mathrm{~m}^{2} \mathrm{ha}^{-1}$, and the crown closure above individual rain gauges was between 19 and $95 \%$. The total interception loss in both growing seasons analyzed was $34.5 \%$. The mean value of the interception capacity determined was about $2 \mathrm{~mm}$. Throughfall exhibited high variability from place to place and it was strongly affected by character of rainfall. On the other hand, spatial pattern of throughfall in average showed low variability.
\end{abstract}

Keywords: Interception loss; Interception capacity; Free throughfall; Evaporation; Hydrological balance of vegetation cover.

\section{INTRODUCTION}

During a rainfall event, an important part of the precipitation is intercepted on the surface of vegetation. This process is called interception in the hydrology and it is often neglected for lack of information. The part of precipitation that is captured by vegetation does not contribute to the runoff and is subsequently evaporated back to the atmosphere.

This rainfall partitioning by vegetation alters water fluxes in soil-plant-atmosphere continuum and further enhances the complexity of processes governing the catchment water balance. More specifically, the interception in natural catchments affects plants transpiration (Coenders-Gerrits et al., 2014; Pallardy, 2008), runoff formation (Wang et al., 2012; Zehe et al., 2010) as well as heat and water vapor transport within the atmospheric boundary layer (e.g., van Heerwaarden, 2011). Neglecting or oversimplifying the interception process can significantly deteriorate the evaluation of other individual components of the hydrological balance and consequently the accuracy of climate and hydrological models (Wang and Eltahir, 2000; Zierl, 2001). Better understanding of the interception process will allow reliable estimate of its impacts and effective designing of interception model for the experimental area under study. For this purpose, identification of the key parameters affecting both the intercepted water amount and the rate of its evaporation back to the atmosphere is essential.

Hydrological balance of natural catchments can be written

$$
\Delta S=H_{P}-\left(H_{Q}+H_{E T}\right)
$$

where $\mathrm{S}$ is water storage in the catchment $(\mathrm{mm}), H_{P}$ is rainfall depth measured in open area $(\mathrm{mm}), H_{Q}$ is runoff depth at the catchment outlet (mm), and $H_{E T}$ is amount of evapotranspiration from the catchment $(\mathrm{mm})$. Interception loss is included in the evapotranspiration term of equation (1), formulated at the catchment scale. This is a reason why the interception loss is sometimes called interception evaporation. Nevertheless, its amount is usually expressed as a part of rainfall depth (in percent). The reason is that the interception loss is frequently calculated from the water balance of the vegetation canopy (i.e. independently of evapotranspiration estimation for catchment).

Rainfall character, type of the vegetation cover, and local climatic conditions determine amount of precipitation that reaches soil surface. Precipitation is partitioned due presence of vegetation cover into three parts: (i) a part that remains on vegetation and is evaporated during or after rainfall event (interception loss); (ii) a part that flows to the ground via branches and stems (stemflow); and (iii) a part that in contact or contactless way falls to the ground through the canopy (throughfall).

Thus the water balance of the vegetation canopy could be expressed:

$H_{P}=H_{S F}+H_{T F}+H_{I}$

where $H_{S F}$ is the stemflow (mm), $H_{T F}$ is the rainfall depth measured at forest floor (i.e. throughfall) $(\mathrm{mm})$, and $H_{I}$ is the interception loss $(\mathrm{mm})$. The sum of stemflow and throughall is sometimes called the net rainfall (in forestry also the effective rainfall). The rainfall measured in open area is often called the total rainfall. In case that reliable measurement of each rainfall in open area, stemflow, and troughfall is available, the amount of interception loss can be calculated from the balance equation (2) directly (Brutsaert (2005) or Gerrits (2010) among others). In the present study, $H_{T F}$ is further divided into a part that falls down to the forest floor without any contact with the canopy and a part which drips from the canopy to the forest floor when the interception capacity is exceeded. The first part is called the free (or direct) throughfall and is estimated by within-event regression analysis of precipitation data. The free throughfall together with the above mentioned interception capacity are often used in interception models (e.g., Gash, 1979; Liu, 1997). Thus accurate determination of these parameters presents an important task of experimental hydrology.

The objectives of the present study were threefold. Firstly, to determine the interception loss of Norway spruce trees stand 
based on data from two consecutive vegetation seasons and to compare these values with values published for forest ecosystems of similar species composition. Secondly, to estimate the interception capacity of the spruce forest on the experimental area. Thirdly, to analyze spatial variability of the throughfall.

\section{MATERIAL AND METHODS \\ Experimental area}

Liz experimental catchment is a small mountainous watershed situated in the lower part of the Bohemian Forest, $6.5 \mathrm{~km}$ in the northwest direction from Vimperk, operated by Institute of Hydrodynamics of the Academy of Sciences of the Czech Republic (Tesař et al., 2006). It has been subject to long term monitoring of the hydrological and climatic regime. Catchment Liz is part of the Volyňka watershed and continuous hydrological data are available for the last nearly 40 years (from November 1975). The catchment area is $0.99 \mathrm{~km}^{2}$, the average altitude $941 \mathrm{~m}$ a.s.l. (ranging from 827 to $1074 \mathrm{~m}$ a.s.1.), the mean annual precipitation $863 \mathrm{~mm}$, the mean annual runoff depth $345 \mathrm{~mm}$, and the mean annual temperature $6.6^{\circ} \mathrm{C}$ (values determined for hydrological years 1976-2013).

Table 1. Basic characteristics of spruce trees at experimental area.

\begin{tabular}{|c|c|c|}
\hline Tree No. & $\begin{array}{l}\text { Diameter at breast height } \\
(\mathrm{cm})\end{array}$ & $\begin{array}{c}\text { Crown area } \\
\left(\mathrm{m}^{2}\right)\end{array}$ \\
\hline 1 & 45.9 & 22.0 \\
\hline 2 & 34.4 & 12.5 \\
\hline 3 & 32.5 & 11.2 \\
\hline 4 & 50.3 & 26.3 \\
\hline 5 & 45.5 & 21.7 \\
\hline 6 & 36.0 & 13.7 \\
\hline 7 & 43.6 & 19.9 \\
\hline 8 & 40.8 & 17.4 \\
\hline 9 & 29.9 & 9.6 \\
\hline 10 & 37.9 & 15.1 \\
\hline 11 & 36.6 & 14.2 \\
\hline 12 & 36.3 & 13.9 \\
\hline 13 & 39.2 & 16.1 \\
\hline 14 & 34.7 & 12.8 \\
\hline 15 & 36.9 & 14.4 \\
\hline 16 & 38.2 & 15.4 \\
\hline 17 & 29.9 & 9.6 \\
\hline 18 & 45.2 & 21.4 \\
\hline 19 & 38.9 & 15.9 \\
\hline 20 & 35.0 & 13.0 \\
\hline 21 & 32.5 & 11.2 \\
\hline 22 & 35.4 & 13.2 \\
\hline 23 & 41.7 & 18.3 \\
\hline 24 & 33.8 & 12.1 \\
\hline 25 & 41.4 & 18.0 \\
\hline 26 & 36.6 & 14.2 \\
\hline 27 & 42.4 & 18.8 \\
\hline
\end{tabular}

The experimental area $\left(565 \mathrm{~m}^{2}\right)$ is situated at the lower part of the Liz experimental catchment (mean altitude of the plot is
$857.7 \mathrm{~m}$ a.s.1.). The research plot lies on the slope with southern orientation and declination of $10^{\circ}$. Forest cover on the experimental area is formed by $80-90$ years old Norway spruce specimens exclusively (Picea abies (L.) Karst.) with a height of about $28 \mathrm{~m}$ and mean diameter of $38 \mathrm{~cm}$ (for details see Table 1). The basal area of conifers at the experimental area was estimated to be $55.7 \mathrm{~m}^{2} \mathrm{ha}^{-1}$. The forest floor consists of sparse grass and organic litter, shrubs are not present.

Recent research utilizing data from Liz experimental catchment included studies on evapotranspiration (Pražák et al., 1996), cloud and fog water deposition (Eliáš et al., 1995), water regime affected by vegetation cover changes (Buchtele et al., 2006), hydraulic redistribution of water by roots (Nadezhdina et al., 2010), development and testing of macroscopic root water uptake model (Vogel et al., 2013), and predictions of heat fluxes in structured soil profile (Votrubová et al., 2012).

\section{Rainfall, throughfall and stemflow monitoring}

Meteorological observations are situated at a mountain meadow in the lower part of the catchment (open area) and at the experimental area within the forested part of the catchment. At both sides, precipitation intensities are recorded by weighing rain gauges MRW500 (Meteoservis v.o.s.) with catchment area of $500 \mathrm{~cm}^{2}$ (hereafter denoted as WRG-OA for rain gauge in open area and WRG-SF for rain gauge at spruce forest floor). The upper edge of rain gauges is situated at a height of $1 \mathrm{~m}$ above the ground. Measurement accuracy is $\pm 0.1 \mathrm{~mm}$ and does not depend on the intensity of precipitation. Distance between these two rain gauges is about $400 \mathrm{~m}$. Five tipping bucket rain gauges (TBRG) with similar accuracy are used to capture throughfall variability at the forested site (see Fig. 1 and Table 2). The locations of the rain gauges were selected with respect to biometric characteristics of the forest canopy in order to measure precipitation near the stem (TBRG 3), at the dripping zone - i.e. under tree branches - (TBRG 1, 2, 4 and WRG-SF) and in the forest windows (TBRG 5). Similar arrangement is used by Holko et al. (2009) among others.

Tipping bucket rain gauges are prone to be clogged with dead spruce needles, pollen, insects and the other organic matter. Therefore the rain gauges were checked weekly and all suspicious throughfall data were excluded from the analysis. In the present study, spruce forest interception is studied for two consecutive vegetation seasons 2012 and 2013 (from June to October in 2012, and from April to October in 2013). All rain gauge data are collected with 15-min time step.

Stemflow is captured by circumferential collars at selected tree specimens (trees No. 4, 5 and 18; Table 1, Fig. 1). Gathered water amount is subsequently measured by tipping bucket flowmeter with the resolution of $0.1 \mathrm{~mm}$ per tip or collected to PE bottles. The collar is formed by a small tire wrapped around the tree, attached with galvanized iron nails, filled by polyurethane foam and finally sealed with neutral silicone sealant. Similar measurement of stemflow was reported e.g. by Crockford and Richardson (2000).

The occurrence and duration of fogs was assessed using PWD-11 sensor (Present Weather Detector, Vaisala, Finland) placed in the open area, the duration of the precipitation was evaluated with the help of rain detector which is a part of the weighing rain gauge WRG-OA. Results from long-term fog water deposition monitoring at Liz catchment were analyzed by Eliáš et al. (1995) or Fišák et al. (2002). 


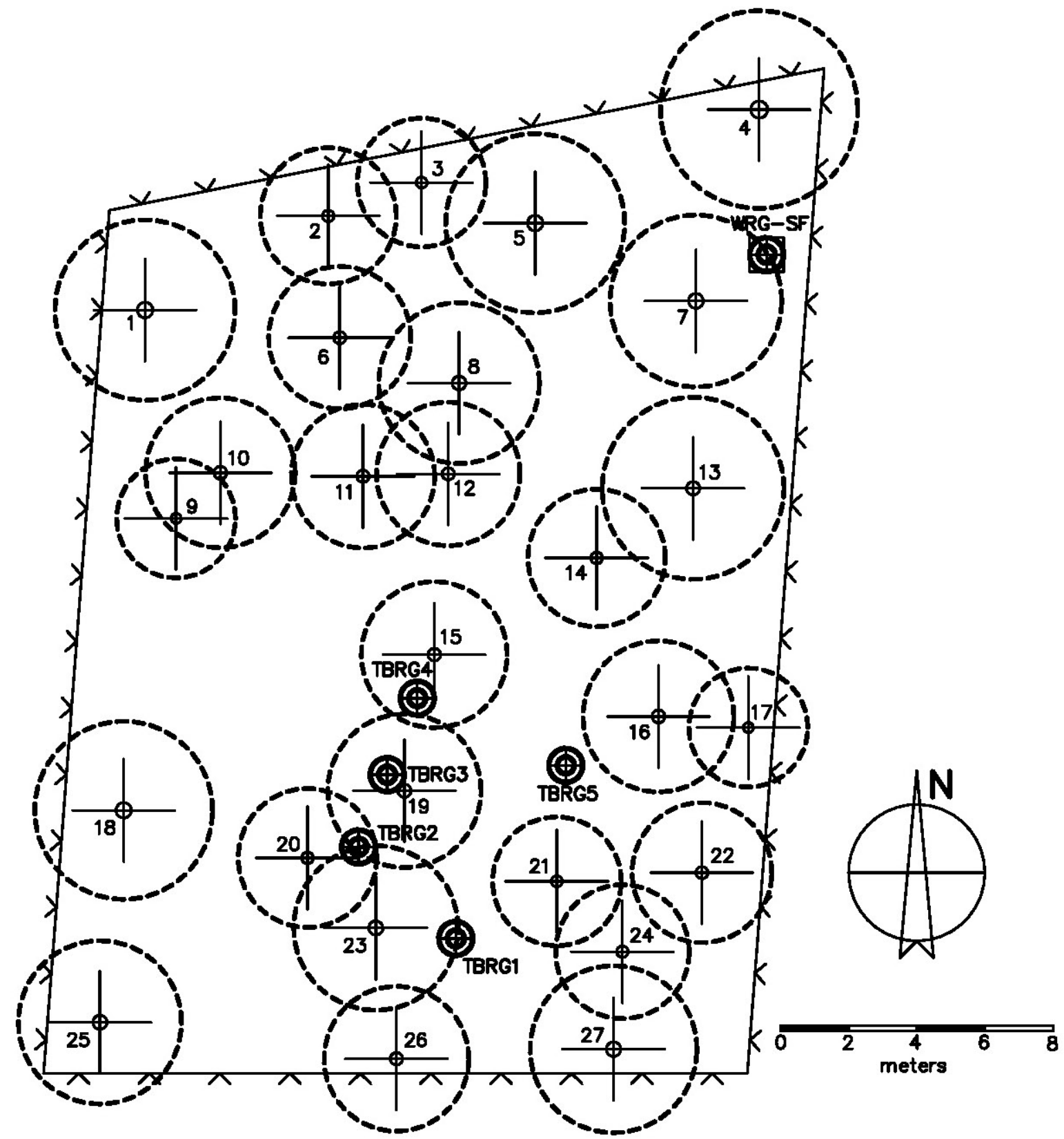

Fig. 1. Scheme of the experimental site at Liz catchment. Tree stems and schematic crown outlines are depicted together with rain gauges. Abbreviations: TBRG tipping bucket rain gauge, WRG weighing rain gauge. For tree data see Table 1.

Table 2. Description of rain gauges.

\begin{tabular}{ccccc}
\hline Name & Location & Type & $\begin{array}{c}\text { Catchment area } \\
\left(\mathrm{cm}^{2}\right)\end{array}$ & $\begin{array}{c}\text { Altitude of the top } \\
\text { edge } \\
(\mathrm{m} \text { a.s.l. })\end{array}$ \\
\hline WRG-SF & forest floor & weighing $^{*}$ & 500 & 860,1 \\
WRG-OA & open area & $\begin{array}{c}\text { weighing } \\
{ }^{*}\end{array}$ & 500 & 830,2 \\
TBRG1 & forest floor & tipping bucket & 500 & 857,1 \\
TBRG2 & forest floor & tipping bucket & 500 & 857,4 \\
TBRG3 & forest floor & tipping bucket & 500 & 857,9 \\
TBRG4 & forest floor & tipping bucket & 500 & 858,2 \\
TBRG5 & forest floor & tipping bucket & 500 & 857,7 \\
\hline
\end{tabular}

*The rain gauge is heated. 


\section{Estimation of interception capacity and free throughfall}

The high frequency measurement allowed analyzing separate rainfall episodes in detail. Based on data from the weighing rain gauge, 16 distinct rainfall episodes were detected in 2012 and 23 episodes in 2013. These cover a wide range of rainfall durations (from hours to days) and precipitation amounts (from $2.4 \mathrm{~mm}$ to $72.7 \mathrm{~mm}$ ). The maximum instantaneous rainfall intensity detected was $50 \mathrm{~mm} \mathrm{~h}^{-1}$.

Canopy interception parameters, i.e. the interception capacity and the free throughfall, are commonly derived from the regression analysis of the cumulative precipitation amounts observed in open area and under the tree canopy (e.g. Link et al., 2004; Peng et al., 2014). The free througfall is given by the slope of a linear trend between these two variables at times before the interception capacity of canopy is saturated. Given the data at later times, the interception capacity can be evaluated as the intercept of a linear trend between these two variables with the axis expressing the cumulative rainfall in open area (Leyton et al., 1967; Klaassen et al., 1998).

\section{Estimation of leaf area index}

The value of leaf area index (LAI; for conifers defined as the total area of all needles per unit ground surface area in $\mathrm{m}^{2} \mathrm{~m}^{-2}$ ) was determined with an indirect non-invasive method based on solar radiation reaching a wide-angle optical sensor. Two plant canopy analyzers LAI 2000 (LI-COR Biosciences) were used in experimental area. Twelve measurements were performed during a single campaign in August, 2012. Estimation of LAI followed methodology proposed by Gower and Norman (1990).

\section{Estimation of the crown closure}

Digital single-lens reflex camera NIKON D60 (lens Samyang $8 \mathrm{~mm}$, f 3.5) was used. Images were taken in April, 2014. The crown spruce cover above rain gauges was evaluated by means of digital image analysis using computer program FIJI (Schindelin et al., 2012). Post processing of digital images included image binarization, fine adjustment and fragmentation. Possible changes in crown closure during analyzed vegetation seasons were neglected.

\section{RESULTS AND DISCUSSION \\ Leaf area index of spruce stand}

The minimal estimated value of LAI was $3.54 \mathrm{~m}^{2} \mathrm{~m}^{-2}$ and the maximal value was $3.75 \mathrm{~m}^{2} \mathrm{~m}^{-2}$. Conifer needles are not arranged randomly in space (see for example Norman and Jarvis, 1975). Therefore the measured values were corrected by a factor specific for Norway spruce proposed by Gower and Norman (1990). The range of the corrected values of LAI was 5.66-6.00 $\mathrm{m}^{2} \mathrm{~m}^{-2}$. Pokorný (2002) and Kantor et al. (2009) reported LAI values between 5.94 and $8.22 \mathrm{~m}^{2} \mathrm{~m}^{-2}$ for 21 -year old spruce stands. For monoculture of Norway spruce, similar in age, structure and climatic conditions, Homolová et al. (2007) estimated LAI $5.44 \mathrm{~m}^{2} \mathrm{~m}^{-2}$.

\section{Stemflow and occult precipitations}

Measured values of stemflow were very low in both vegetation seasons (2012 and 2013); in fact, the instantaneous intensities were within the order of magnitude of measurement error. The total volume of stemflow did not exceed $1 \%$ of the precipi- tation in open area for either season analyzed. For this reason the stemflow can be neglected in the studied area when equation (2) is solved. Attention was also paid to wind driven low clouds and fogs water deposition on needles which could significantly affect values of interception capacity. It was found that the occurrence of fogs during the rainfall episodes was very rare for the period studied. The total duration of the fogs with the intensity 2 a 3, i.e. with horizontal visibility less than $200 \mathrm{~m}$, was only 2 hours in 2012 and 12 hours in 2013. Therefore, for the period studied (June - October in 2012 and April - October in 2013), the occurrence and duration of high intensity fogs was found insignificant and thus the effect of occult precipitation was neglected.

\section{Interception loss}

The total interception loss in growing seasons 2012 and 2013 was calculated based on the total precipitation measured in open area and the throughfall measured under the forest canopy (equation 2). It was $48 \%$ of the total precipitation in 2012 and $35 \%$ in 2013. However, a shorter period was considered in 2012 due to data inhomogeneity. Taking into account the same period within each year (i.e. June - October), the interception loss detected was $36 \%$ in 2012 and $33 \%$ in 2013.

The value of interception loss can be related to the age of trees in the stand, value of LAI, spatial distribution of trees or the section of land area occupied by the cross-section of tree trunks at their base (i.e. a basal area). For coniferous trees, the interception loss increases with the basal area; while it is $20 \%$ in stands with the basal area less than $30 \mathrm{~m}^{2} \mathrm{ha}^{-1}$, it reaches $50 \%$ when the basal area exceeds $70 \mathrm{~m}^{2} \mathrm{ha}^{-1}$ (Grelle et al., 1997; Crockford and Richardson, 2000; Barbier et al., 2009). The basal area of conifers at the experimental area was estimated to be $55.7 \mathrm{~m}^{2} \mathrm{ha}^{-1}$.

\section{Interception capacity and free throughfall}

Both the interception capacity and the free throughfall were evaluated based on regression analysis of data measured for separate rainfall events, namely the cumulative precipitation

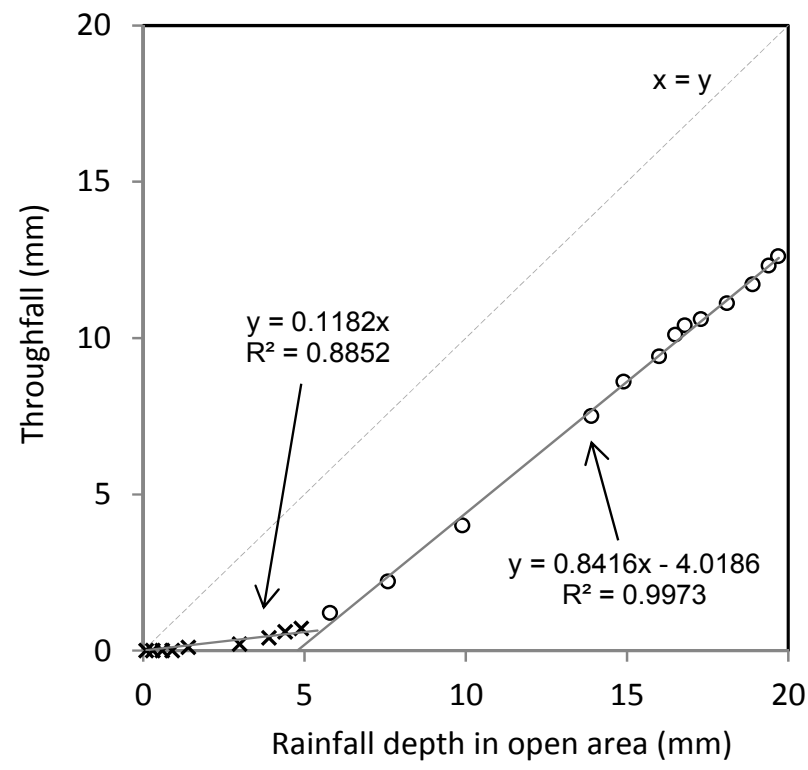

Fig. 2. Regression analysis of rainfall event on September 25-26, 2012. 
amounts observed in open area and under the tree canopy. In Fig. 2, data obtained for a rainfall event on September 25-26, 2012 are presented. A clear change of slope of presented relationship enables dividing the rainfall data into two phases, before and after saturation of the canopy interception capacity. The slope of a line fitted to the data obtained before saturation of the interception capacity is 0.118 , indicating that the free throughfall is $11.8 \%$ of the total rainfall. The interception capacity derived from the rest of the data is $4.8 \mathrm{~mm}$. The slope of the fitted line in this second phase of the rainfall event is less than one. This is usually attributed to evaporation of a part of intercepted water during the rainfall event.

Table 3. The interception capacity and the free throughfall of Norway spruce forest stand at the experimental catchment Liz in 2012 . Missing values could not be determined reliably.

\begin{tabular}{|c|c|c|c|c|c|c|}
\hline Episode No. & Month/Year & $\begin{array}{c}\text { Rainfall } \\
\text { depth}^{*} \\
(\mathrm{~mm})\end{array}$ & $\begin{array}{c}\text { Rainfall dura- } \\
\text { tion } \\
\text { (min) } \\
\end{array}$ & $\begin{array}{c}\text { Interception } \\
\text { loss }^{* *} \\
(\mathrm{~mm}) \\
\end{array}$ & $\begin{array}{c}\text { Free through- } \\
\text { fall } \\
(\%) \\
\end{array}$ & $\begin{array}{c}\text { Interception capacity } \\
(\mathrm{mm}) \\
\end{array}$ \\
\hline I & $6 / 12$ & 2.4 & 285 & 1.9 & 18.9 & - \\
\hline II & $7 / 12$ & 7.2 & 150 & 3.6 & 8.5 & 3.0 \\
\hline III & $7 / 12$ & 17.3 & 270 & 2.9 & - & 1.5 \\
\hline IV & $7 / 12$ & 4.5 & 390 & 2.3 & 13.8 & 0.7 \\
\hline $\mathrm{V}$ & $8 / 12$ & 15.4 & 135 & 7.5 & - & 0.6 \\
\hline VI & $8 / 12$ & 7.3 & 285 & 3.9 & - & 1.5 \\
\hline VII & $8 / 12$ & 19.7 & 390 & 7.1 & 11.7 & 4.8 \\
\hline VIII & $9 / 12$ & 4.3 & 750 & 0.6 & 20.5 & 0.5 \\
\hline IX & $9 / 12$ & 4.4 & 480 & 1.5 & 20.7 & 1.4 \\
\hline $\mathrm{X}$ & $9 / 12$ & 19.2 & 1245 & 10.2 & 16.7 & 4.5 \\
\hline XI & $10 / 12$ & 7.8 & 495 & 5.9 & 8.9 & 3.4 \\
\hline XII & $10 / 12$ & 13.3 & 1305 & 5.2 & 41.1 & 1.8 \\
\hline XIII & $7 / 12$ & 5.5 & 150 & 3.6 & 27.5 & 1.6 \\
\hline XIV & $8 / 12$ & 36.6 & 285 & 5.9 & - & 3.4 \\
\hline $\mathrm{XV}$ & $9 / 12$ & 2.8 & 360 & 2.0 & 18.4 & 1.4 \\
\hline XVII & $10 / 12$ & 4.4 & 480 & 2.6 & 17.5 & 1.6 \\
\hline
\end{tabular}

*The rainfall depth measured in open area.

**Interception loss calculated from equation (2)

Table 4. The interception capacity and the free throughfall of Norway spruce forest stand at the experimental catchment Liz in 2013. Missing values could not be determined reliably.

\begin{tabular}{|c|c|c|c|c|c|c|}
\hline Episode No. & Month/Year & $\begin{array}{l}\text { Rainfall } \\
\text { depth }^{*} \\
(\mathrm{~mm})\end{array}$ & $\begin{array}{c}\text { Rainfall dura- } \\
\text { tion } \\
(\mathrm{min}) \\
\end{array}$ & $\begin{array}{c}\text { Interception } \\
\text { loss } \\
(\mathrm{mm}) \\
\end{array}$ & $\begin{array}{c}\text { Free through- } \\
\text { fall } \\
(\%) \\
\end{array}$ & $\begin{array}{c}\text { Interception capacity } \\
(\mathrm{mm})\end{array}$ \\
\hline I & $4 / 13$ & 5.1 & 105 & 1.4 & 11.9 & 1.6 \\
\hline II & $5 / 13$ & 14.2 & 315 & 5.2 & - & 1.7 \\
\hline III & $5 / 13$ & 15.4 & 765 & 3.0 & 33.4 & 1.7 \\
\hline IV & $5 / 13$ & 6.9 & 600 & 3.2 & 12.0 & 0.7 \\
\hline V & $5 / 13$ & 7.9 & 150 & 2.0 & 36.3 & - \\
\hline VII & $5 / 13$ & 8.3 & 555 & 3.8 & 14.4 & 1.8 \\
\hline VIII & $5 / 13$ & 9.5 & 450 & 1.2 & 30.2 & 0.5 \\
\hline IX & $6 / 13$ & 72.7 & 2370 & 7.1 & 26.2 & 5.5 \\
\hline $\mathrm{X}$ & $6 / 13$ & 4.7 & 570 & 1.9 & 9.2 & 0.8 \\
\hline XI & $6 / 13$ & 9.8 & 180 & 2.1 & 24.8 & 3.0 \\
\hline XIII & $6 / 13$ & 5.9 & 390 & 3.8 & 21.6 & 1.2 \\
\hline XIV & $7 / 13$ & 8.0 & 210 & 2.1 & 10.7 & - \\
\hline $\mathrm{XV}$ & $8 / 13$ & 19.1 & 150 & 7.3 & - & 2.1 \\
\hline XVI & $8 / 13$ & 11.4 & 210 & 2.5 & 45.4 & 3.5 \\
\hline XVII & $8 / 13$ & 19.8 & 375 & 4.4 & - & 0.7 \\
\hline XVIII & $8 / 13$ & 9.7 & 225 & 2.0 & 24.4 & 0.8 \\
\hline XX & $6 / 13$ & 31.8 & 1170 & 3.1 & 20.0 & 2.5 \\
\hline XXI & $6 / 13$ & 2.6 & 180 & 1.3 & 22.6 & 0.7 \\
\hline XXII & $4 / 13$ & 4.0 & 450 & 2.9 & 7.3 & - \\
\hline XXIII & $4 / 13$ & 22.7 & 1425 & 3.6 & 16.4 & 2.7 \\
\hline XXIV & $6 / 13$ & 5.7 & 375 & 4.2 & 10.9 & 1.7 \\
\hline XXV & $9 / 13$ & 9.1 & 210 & 4.4 & - & 1.2 \\
\hline XXVI & $9 / 13$ & 13.0 & 1290 & 6.9 & 11.8 & 5.4 \\
\hline
\end{tabular}

*The rainfall depth measured in open area.

**Interception loss calculated from equation (2). 
Results obtained for seasons 2012 and 2013 are presented in Table 3 and Table 4 respectively. Mean value of the interception capacity determined for Picea abies was $2.1 \mathrm{~mm}$ in 2012 and $2.0 \mathrm{~mm}$ in 2013. These values are close to results of Majerčáková (1984) for spruce stand in Central Slovakia and in the range of values of interception capacity summarized by Breuer et al. (2003).

Estimated values of the free throughfall were $18.7 \%$ and $20.5 \%$ in 2012 and 2013 respectively. The highest value of interception capacity was detected for precipitation on June 1-3, $2013(5.5 \mathrm{~mm})$. This event had also the longest duration (2370 $\mathrm{min}$ ) of all analyzed events. In this case, the interception capacity was probably strongly affected by evaporation. Overall variability of interception capacity values reported in Table 3 and 4 could be related to differences in wind velocity and distribution of rain drop diameters during separate rainfall events. However, none of these effects is analyzed in present study due to lack of measured data.

All detected values of free throughfall were in the range of $7-45 \%$. However, in almost one third of cases any value of free throughfall could not be determined. Generally, these were cases of short intensive storms for which high values of free troughfall are expected (due to strong winds and high kinetic energy of water drops). Failing of the methodology in these cases was probably related to a time shift of the storm onset between the sites where the precipitation was measured (either in open space or under the tree canopy). The distance between the rain gauges is quite large and the impact on the data obtained for convective cells within passing storms, associated with the most intensive precipitation, was found crucial.

\section{Spatial variability of throughfall}

Spatial variability of throughfall at the forested site was studied using a set of six rain gauges (see Fig. 1 and Table 5). Values of the crown closure at the forested site studied ranged between 19 and $95 \%$. The average value of crown closure was $69 \%$.

Throughfall was highly variable in space during rainfall events analyzed. Thus the calculated interception losses differed from place to place dramatically (in tens of percent). For example, in vegetation season 2013, 25 events analyzed showed average interception loss about $36 \%$ with minimum $0 \%$, maximum $80 \%$ and standard deviation $18.6 \%$. Similarly Holko et al. (2009) observed the spatial variability of spruce forest rainfall interception in tens of percent.

Also the dynamics of interception process varied between individual places. This can be illustrated with temporal development of cumulative forest floor rainfall intensities (see rain gauges No. 1 and No. 5 in the Fig. 3). Moreover, throughfall observed in episodes does not strictly follow expectations that arise from crown closure above rain gauge (Fig. 3 - rain gauges No. 1 and weighing rain gauge). This discrepancy could be caused by character of rainfall and the prevailing wind direction (issue has not yet been analyzed).

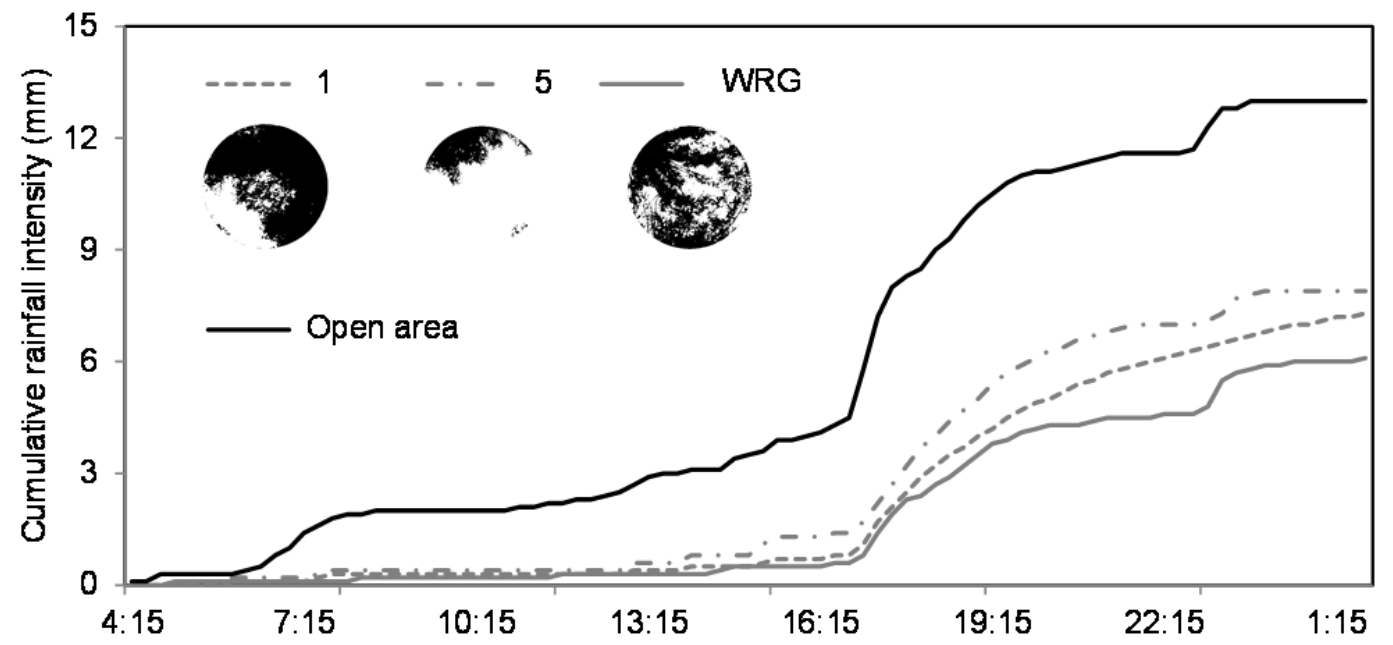

Fig. 3. Spatial variability of throughfall during rainfall episode from September 18, 2013. The crown closure above selected rain gauges is depicted by binarized digital images. Note that crown closure was $73 \%$ for rain gauge No. $1,19 \%$ for No. 5 and $60 \%$ for weighing rain gauge (WRG).

Table 5. Spatial variability of within-event determined interception parameters. Mean values of interception capacity and free throughfall are presented.

\begin{tabular}{lccccc}
\hline Name & Crown closure & $\begin{array}{c}\text { Interception } \\
\text { capacity } \\
(\mathrm{mm})\end{array}$ & $\begin{array}{c}\text { Free } \\
\text { throughfall } \\
(\%)\end{array}$ & $\begin{array}{c}\text { Interception } \\
\text { capacity } \\
(\mathrm{mm})\end{array}$ & $\begin{array}{c}\text { Free } \\
\text { throughfall } \\
(\%)\end{array}$ \\
\hline WRG & $(\%)$ & 2.1 & 18.7 & 2.0 & 20.5 \\
TBRG1 & 73 & 1.7 & 21.2 & 1.5 & 21.3 \\
TBRG2 & 88 & 2.5 & 18.7 & 1.6 & 23.0 \\
TBRG3 & 95 & 1.7 & 15.4 & 2.4 & 18.9 \\
TBRG4 & 77 & 1.7 & 16.5 & 1.6 & 24.5 \\
TBRG5 & 19 & 2.3 & 50.5 & 1.7 & 47.9 \\
\hline
\end{tabular}




\section{Spatial variability of within-event determined free throughfall}

Seasonal throughfall measurements show high temporal stability (Table 5). Temporal change in the average interception capacity between seasons 2012 and 2013 was less than 36\%. The highest difference in the free throughfall was only $8 \%$. These seasonally averaged data illustrate stability of the spatial pattern in forest under study. Fairly constant throughfall values after completion of canopy closure reported also Waterloo (1994).

An overview of the free throughfall-crown closure relation is displayed in Fig. 4. Data from both seasons are included. Values of free throughfall show high variance (widely spread around the mean) for small crown closure. Observed free throughfall is much smaller for higher values of crown closure. In general estimated free throughfall seems to be exponentially decreasing with increasing amount of crown closure.

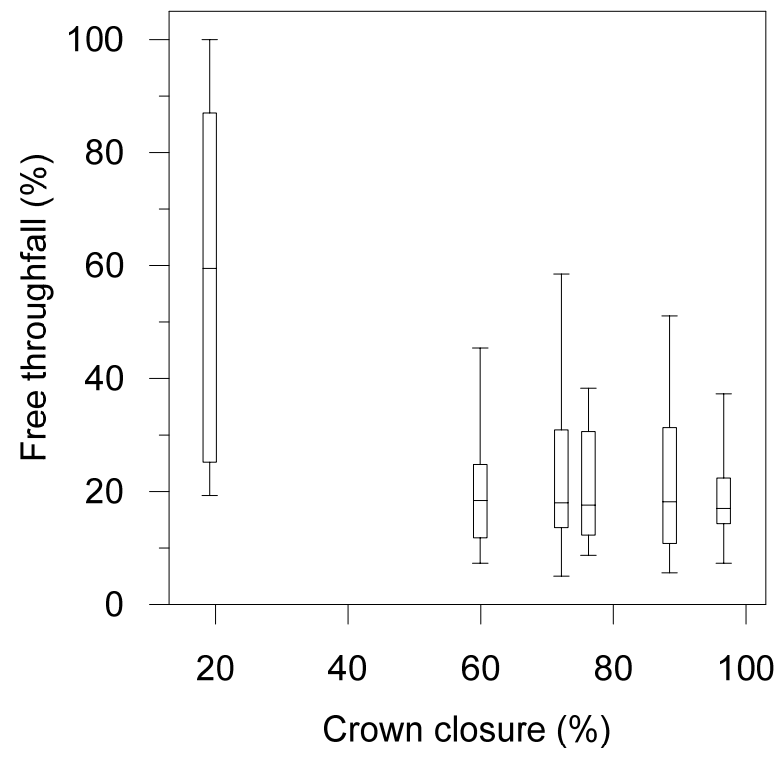

Fig. 4. Relationship between the crown closures above the rain gauges and the free throughfall percentage. Minimum and maximum values, the upper and lower quartiles and the median of estimated free througfall are displayed. Note that data from all available rainfall episodes in vegetation seasons 2012 and 2013 were used.

\section{CONCLUSIONS}

Rainfall interception by spruce forest at Liz experimental watershed, Bohemian Forest, was examined. Data from rainfall monitoring in 2012 and 2013 were analyzed. The total interception loss was determined based on precipitation measured in open area and under the trees; it was $36 \%$ for the period from June to October 2012 and 33\% for the same period in 2013. These results were compared with values published for coniferous tree stands of various basal areas. It was found that the total interception loss at the experimental site is slightly higher than it was detected for other similar tree stands.

Mean value of the interception capacity determined for Picea abies under study was $2.1 \mathrm{~mm}$ in 2012 and $2.0 \mathrm{~mm}$ in 2013 . Estimated amount of precipitation that falls down in contactless way through crowns were $18.7 \%$ and $20.5 \%$ in 2012 and 2013 respectively (for weighing rain gauge).
Spatial variability of throughfall was studied using six rain gauges. Throughfall exhibits high spatial variability and it is strongly affected by character of rainfall. On the other hand, temporal variability of the spatial patterns of throughfall in average is low.

Acknowledgement. The research was supported by the Technology Agency of the Czech Republic (TA02021451) and the Ministry of Education of the Czech Republic (Institutional support for long-term conceptual development). Special thanks are due to Dr. Zumr, Dr. Sněhota, and Dr. Dušek for their help with LAI measurements. The optical sensor LAI 2000 was kindly provided by the University on Natural Resources and Life Sciences, Vienna

\section{REFERENCES}

Barbier, S., Balandier, P., Gosselin, F., 2009. Influence of several tree traits on rainfall partitioning in temperate and boreal forests: a review. Annals of Forest Science Journal, 66, 602.

Breuer, L., Eckhardt, K., Frede, H.-G., 2003. Plant parameter values for models in temperate climates. Ecological Modelling, 169, 237-293.

Brutsaert, W., 2005. Hydrology: An introduction. Cambridge University Press, Cambridge.

Buchtele, J., Buchtelová, M., Tesař, M., 2006. Role of vegetation in the variability of water regimes in the Śumava Mts. forest. Biologia, 61, S246-S250.

Coenders-Gerrits, A.M.J., van der Ent, R.J., Bogaard, T.A., Wang-Erlandsson, L., Hrachowitz, M., Savenije, H.H.G., 2014. Uncertainties in transpiration estimates. Nature, 506, E1-E2.

Crockford, R.H., Richardson, D.P., 2000. Partitioning of rainfall into throughfall, stemflow and interception: effect of forest type, ground cover and climate. Hydrological Processes, 14, $2903-2920$

Eliáš, V., Tesař, M., Buchtele, J., 1995. Occult precipitation: sampling, chemical analysis and process modelling in the Sumava Mts. (Czech Republic) and in the Taunus Mts. (Germany). J. Hydrol., 166, 409-420.

Fišák, J., Tesař, M., Řezáčová, D., Eliáš, V., Weignerová, V., Fottová, D., 2002. Pollutant concentrations in fog and low cloud water at selected sites of the Czech Republic. Atmospheric Research, 64, 75-87.

Gash, J.H.C., 1979. An analytical model of rainfall interception by forests. Q.J.R. Met. Soc., 105, 43-55.

Gerrits, A.M.J., 2010. The role of interception in the hydrological cycle. PhD thesis. Delft University of Technology, Delft, $146 \mathrm{pp}$.

Gower, S.T., Norman, J.M., 1990. Rapid estimation of leaf area index in forests using the LI-COR LAI-2000. Ecology, 72, 1896-1900.

Grelle, A., Lundberg, A., Lindroth, A., Morén, A.-S., Cienciala, E., 1997. Evaporation components of a boreal forest: variations during the growing season. Journal of Hydrology, 197, $70-87$.

Holko, L., Škvarenina, J., Kostka, Z., Frič, M., Staroň, J., 2009. Impact of spruce forest on rainfall interception and seasonal snow cover evolution in the Western Tatra Mountains, Slovakia. Biologia, 64, 594-599.

Homolová, L., Malenovský, Z., Hanuš, J., Tomášková, I., Dvořáková, M., Pokorný, R., 2007. Comparison of different ground techniques to map leaf area index of Norway spruce forest canopy. In: Proc. $10^{\text {th }}$ International symposium on 
Physical measurements and signatures in remote sensing, ISPMSRS 2007, Davos.

Kantor, P., Šach, F., Černohous, V., 2009. Development of foliage biomass of young spruce and beech stands in the mountain water balance research area. Journal of Forest Science, 55, 51-62.

Klaassen, W., Bosveld, F., de Water, E., 1998. Water storage and evaporation as constituents of rainfall interception. J. Hydrol., 212-213, 36-50.

Leyton, L., Reynolds, E.R.C., Thompson, F.B., 1967. Rainfall interception in forest and moorland. In: Sopper, W.E., Lull, H.W. (Eds.): Proc. Int. symp. on Forest hydrology, Pergamon Press, New York, pp.163-168.

Link, T.E., Unsworth, M., Marks, D., 2004. The dynamics of rainfall interception by a seasonal temperate rainforest. Agricultural and Forest Meteorology, 124, 171-191.

Liu, S., 1997: A new model for the prediction of rainfall interception in forest canopies. Ecological Modelling, 99, 151159.

Majerčáková, O., 1984. Modeling of interception as a loss component in the process of runoff generation. J. Hydrol. Hydromech., 32, 364-379. (In Slovak).

Nadezhdina, N., David, T.S., David, J.S., Ferreira, M.I., Dohnal, M., Tesar̆, M. et al., 2010: Trees never rest: the multiple facets of hydraulic redistribution. Ecohydrol., 3, 431444.

Norman, J.M., Jarvis, P.G., 1975. Photosynthesis in Sitka spruce, V. Radiation penetration theory and a test case. Journal of Applied Ecology, 12, 839-878.

Pallardy, S.G., 2008. Physiology of Woody Plants. Third Edition. Elsevier Inc., London, UK.

Peng, H., Zhao, C., Feng, Z., Xu, Z., Wang, C., Zhao, Y., 2014. Canopy interception by a spruce forest in the upper reach of Heihe River basin, Northwestern China. Hydrological Processes, 28, 1734-1741.

Pokorný, R., 2002. Leaf area index in forest stands. PhD Thesis. Mendel University, Brno.

Pražák, J., Šír, M., Tesař, M., 1996. Parameters determining plant transpiration under conditions of sufficient soil moisture. J. Hydrol., 183, 425-431.
Schindelin, J., Arganda-Carreras, I., Frise, E., Kaynig, V., Longair, M., Pietzsch, T., Preibisch, S., Rueden, C., Saalfeld, S., Schmid, B., Tinevez, J.-Y., White, D.J., Hartenstein, V., Eliceiri, K., Tomancak, P., Cardona, A., 2012. Fiji: an opensource platform for biological-image analysis. Nature Methods, 9, 676-682.

Tesař, M., Balek, J., Šír, M., 2006. Hydrological research in the Volyňka basin (Bohemian Forest, Czech Republic). J. Hydrol. Hydromech., 54, 137-150.

van Heerwaarden, C.C., 2011. Surface evaporation and water vapor transport in the convective boundary layer. $\mathrm{PhD}$ Thesis. Wageningen University, Wageningen, $158 \mathrm{pp}$.

Vogel, T., Dohnal, M., Dušek, J., Votrubová, J., Tesař, M., 2013. Macroscopic modeling of plant water uptake in a forest stand involving root-mediated soil water redistribution. Vadose Zone J., 12, doi:10.2136/vzj2012.0154.

Votrubová, J., Dohnal, M., Vogel, T., Tesař, M., 2012. On parameterization of heat conduction in coupled soil water and heat flow modelling. Soil Water Res., 7, 125-137.

Wang, G.L., Eltahir, E.A.B., 2000. Modeling the biosphereatmosphere system: The impact of the subgrid variability in rainfall interception. Journal of Climate, 13, 2887-2899.

Wang, G.X., Liu, G.S., Li, C.J., 2012: Effects of changes in alpine grassland vegetation cover on hillslope hydrological processes in a permafrost watershed. Journal of Hydrology, 444, 22-33.

Waterloo, M.J., 1994. Water and nutrient dynamics of Pinus Caribea plantation forests on former grassland soils in Southwest Viti Levu, Fiji. Vrije Universiteit, Amsterdam, $478 \mathrm{pp}$.

Zehe, E., Graeff, T., Morgner, M., Bauer, A., Bronstert, A., 2010: Plot and field scale soil moisture dynamics and subsurface wetness control on runoff generation in a headwater in the Ore Mountains. Hydrology and Earth System Sciences, $14,873-889$.

Zierl, B., 2001. A water balance model to simulate drought in forested ecosystems and its application to the entire forested area in Switzerland. J. Hydrol., 242, 115-136.

Received 12 June 2014 Accepted 5 September 2014 